\section{Racial Pride and Prejudice}

By Eric John Dingwall. Pp. $x+246$. (London : Watts and Co., Ltd., 1946.) $8 s .6 d$. net.

7 HIS book deals with an important world problem from the point of view of the anthropologist and the psychologist. It is intended for the general reader rather than the student of either of these sciences, and Dr. Dingwall is to be congratulated on the way he has managed to avoid technical language except where it is absolutely necessary. The book has another great advantage in that the author is not only content to present the facts as he sees them, but also does not hesitate to insert short discussions of the possible reasons that lie behind customs and legislation associated with the colour bar. The combined presentation makes admirable reading. It is unnecessary in a notice of this character to stress the sane, but nevertheless realistic, point of view of the author; it would be more appropriate to direct attention to other special merits that the book possesses. One of these is the admirable psychological approach to the problem of prejudices in general and colour prejudice in particular, and Chapter 14 on the psychology of racial and colour prejudice is a masterful essay in itself. The reader is impressed particularly by the part that jealousy plays in this respect.

To the geography student the book has yet another distinct advantage in so far that the treatment is global. There are chapters on the colour bar in the United States of America, Great Britain, Africa, the West Indies, India and the East, Brazil, Australia and New Zealand, and the U.S.S.R. Such a complete world survey is admirable and will be much appreciated by the student of human geography. The author states in his preface that references and footnotes have been cut down so far as is possible in a book of this kind, and that if authority were to be quoted for every statement the bulk of the book would be almost double and its value would not have been increased in proportion. Nevertheless, the addition of a few well-selected maps showing, for example, the distribution of the Negro population in the United States, or the white population in the Union of South Africa, would be most welcome. The general reader, for whom this volume was written, is ignorant of these essential facts, and while the addition of a few distribution maps would not have made the volume more bulky, it would have increased its value very considerably.

E. G. BOWEN

\section{Introductory College Chemistry}

By Prof. Harry N. Holmes. Fourth edition. Pp. $x+590$. (New York: The Macmillan Company; London: Macmillan and Co., Ltd., 1946.) 18s. net. 7 HIS very attractive book is now in a fourth edition and has been considerably revised. Although its title, and the statement in the preface that it "is of full college grade", stuggest a moderately advanced book, it is really of a standard that would be used in schools in England, and in many parts does not reach Higher School Certificate level. The charts and illustrations are often suitable only for very immature students.

The sections on the metals are dispersed, group methods of preparation and group reactions being stressed. The physical chemistry is presented in some detail, and there are whole chapters on the structure of the atom and nuclear chemistry. Chapters on organic chemistry include matters of technical interest or of importance in daily life, such as hydro- carbons, rubber, carbohydrates, plastics, and food and nutrition. There are references to literature (including some English journals) and questions. In many cases the information is very slight: the only property of carbon disulphide (which has five lines of text) mentioned being that "one pound is needed in the manufacture of three pounds of viscose rayon". The sections on selenium and tellurium, on the other hand, extend over nearly two pages. The validity of the formulæ of orthonitric acid on p. 303, with 5 -valent nitrogen, is doubtful. Mercurous compounds are formulated with univalent mercury. These are minor points; generally the text is very clear and accurate.

What will interest most readers is the very large number of out-of-the-way and striking facts which are worked into the text ; teachers should find many of these likely to stimulate interest. Although the book is not suitable for English school courses, and is much too elementary for junior university use, it is one which can be recommended as likely to be popular in a school library and useful to the teacher. The production is excellent and the price, although rather high for its size, is not prohibitive.

\section{The Scottish Railway Network}

A Project for Reconstructing the Scottish Railways according to certain New Railway Network Principles. By J. F. Pownall. Pp. 72. (Birmingham : Cotterell and Co., 1946.) 8s. $6 d$.

$\mathrm{T}$ this small volume Mr.Pownall returns to an exposition of his hour section principle which he outlined in his "New Railway Network Principles". The present volume deals with Scottish railways. The central idea is that full value cannot be derived from most railway lines because, in spite of good speeds, continuity of movement is hampered. The author would ensure fast journeys on the trunk lines, and the more important branch lines, by recognizing certain "hour stations" on all important routes. Some of these would be stations of present importance to-day, others of little importance and others new stations. Expresses would call at these stations and these only, at precise hour intervals, and connect with slower intermediate trains. Several new lines would be necessary. The scheme is ingenious and deserves consideration in any plans for the modernization of the railways of Great Britain.

\section{The Faroes in Pictures}

By Gordon Huson. Pp. 82. (London : George Allen and Unwin, Ltd., 1946.) 10s. net.

7 HE Faroes are little more than a group of huge volcanic rocks reaching to heights of several thousand feet above sea-level. They lie on the Faroe-Icelandic ridge 200 miles from the nearest land, which is Scotland. Rainy, windswept and infertile though the islands are, their growing population numbers nearly thirty thousand and is fairly homogeneous of early Norse descent. Only three per cent of the land area is cultivated, and most of that is used for sheep grazing. The main occupations are fishing and whaling. The comparatively small caaing or grind whale is caught in numbers. Little in English has been written on these Danish islands. The exigencies of war led to a British garrison, and Major Huson, who was in that garrison, has produced a charming and useful book of pictures to which is attached a very brief account of the islands. The pictures give an excellent idea of the land forms and the surface conditions. 